解 説

\title{
農地管理による土壤炭素貯留効果と気候変動の緩和
}

白戸 康人

\section{Soil Carbon Sequestration by Cropland Management and Mitigation of Climate Change}

\author{
Yasuhito SHIRATO
}

Synopsis: Soil organic carbon (SOC) is a huge and important component of the global carbon cycle. Agricultural soils can be either a sink or a source of atmospheric $\mathrm{CO}_{2}$, depending on the balance between the input of carbon (C) to soils and the output of $\mathrm{C}$ through decomposition. We can change this balance by changing agricultural soil management, understanding the mechanisms of SOC turnover. Not only the quantity but also the quality of input $\mathrm{C}$ affects SOC balance, and environmental conditions such as temperature and moisture of soils as well as inherent properties of soils such as texture affect the decomposition rate of SOC. Since there are many factors affecting SOC balance, SOC turnover models are very useful tools to evaluate the effect of management practices on SOC balance. The RothC model, one of leading SOC models in the world, was validated against long-term experiments in Japan and Thailand, and modified RothC models for paddy soils and for Andosols was developed. The country scale potential of soil carbon sequestration was estimated, then, by using the RothC model for Japanese arable lands. The use of LCA, which includes not only changes in SOC, but also $\mathrm{CO}_{2}$ emissions from the use of fossil fuel in agricultural production processes, is effective and essential in evaluating the effects of agricultural management practices on climate change mitigation. It is important, too, to include other green house gases $\left(\mathrm{CH}_{4}\right.$ and $\left.\mathrm{N}_{2} \mathrm{O}\right)$, other environmental impacts (e.g. nitrate nitrogen in soils and water), and impacts on agricultural productivity, in evaluation of agricultural management practices.

Keywords: Agricultural soils; carbon sequestration; climate change; mitigation; soil organic matter

\section{1. 土壤炭素と気候変動緩和の関係}

IPCC (Intergovernmental Panel on Climate Change: 気 候変動に関する政府間パネル）の第 4 次評価報告書（IPCC, 2007）は、「地球温暖化を引き起こす $\mathrm{CO}_{2}$ などの温室効果 ガス濃度が上昇している原因は、主として化石エネルギー の消費による $\mathrm{CO}_{2}$ 排出量の増加であること」を以前よりも 断定的に述べた。また、2008年からは、京都議定書の第 1 約束期間（2008〜 2012年）が始まった。日本は、この期 間における国全体の温室効果ガスの排出量を 1990年に比 ベて $6 \%$ 削減する義務があるが、2008年の時点では逆に $1.6 \%$ の増加となっており、今後は一層の削減努力が必要 な状況である。第一の対策となるのは、言うまでもなく、 省エネなどで化石燃料の消費を抑えることであるが、本稿 では、別の点にスポットを当てる。

それは、化石燃料の燃焼ではなく、森林、農地などの「土
地」から放出されたり吸収されたりしている温室効果ガス の存在である。例えば森林伐採などの土地利用変化による $\mathrm{CO}_{2}$ の放出がそれに該当するが、その量は、後述するよう にかなりの大きな量になることが知られている。従って、 土地の管理方法を工夫することによって土地からの温室効 果ガスの排出を減らしたり吸収を増やすことは、有効な温 暖化緩和策のひとつとなる。事実、京都議定書の日本の削 減義務 $6 \%$ のうち $3.8 \%$ は森林吸収源で賄われる予定となっ ている。森林吸収源という言葉からまず連想されるのは、 光合成により $\mathrm{CO}_{2}$ を吸収して生長する樹体部分であろうが、 樹木の下にある土壤の中にも、土壌有機物として多量の炭 素が存在している。土壤有機物は、植物の遺体が土に還っ てできたものなので、土畩炭素は、もとはといえば植物が 光合成して吸収した $\mathrm{CO}_{2}$ に由来する。従って、土䁃中の炭 素が増加すれば、その分、大気中の $\mathrm{CO}_{2}$ が減った勘定にな 
るため、土壌も森林の樹体と同じような意味で $\mathrm{CO}_{2}$ の吸収 源と考えることができる。

地球全体でみると、土壤中には約 $2500 \mathrm{Pg}(\mathrm{Pg}=$ ×゚タグ ラム： $10^{15} \mathrm{~g}$ ) の炭素が存在すると見積もられており、こ れは大気 $\mathrm{CO}_{2}(760 \mathrm{PgC})$ の約 3.3 倍、陸上の植物バイオマ ス $(560 \mathrm{PgC})$ の約 4.5 倍に相当する（Lal, 2004）。地球全 体の土壌炭素量の推定値には幅があり（田村, 1996; 伊藤, 2002)、上記は一例にすぎないが、いずれにしろ土壤中の 炭素量は地球全体で見ると非常に多量であるため、そのわ ずかな増減が地球规模の炭素循環に大きく影響すると考え られている。実際、例えば、先史時代から現在までに土壌 有機物の減少で放出された炭素は、人類が化石燃料の消費 により放出した炭素量の 2 倍以上になるという試算がある (Lal, 2004, 袴田ら, 2000)。わかりやすい例として、もと もと森林や草原だった頃に土壤中に蓄えられていた炭素が、 開墾されて畑になったために次第に分解して減少した場合 などがこれに該当する。

このことは、逆に、劣化した土壤が適切な管理の下で修 復されれば土壇に炭素を蓄積させることにより土壤を炭素 の大きな吸収源とする可能性があることを意味する。もち ろん、全ての農地を太古の昔のような自然植生に戻すこと で先史時代の土壤炭素レベルを復元するのは非現実的では あるが、現在の農地で農業生産を続けながらでも、管理方 法を工夫することにより、土壤中の炭素を増加させること はある程度可能である。実際に、土㙥炭素を増加させるこ とで、地球全体の農地ではどの程度の大きさの炭素吸収に よる気候変動緩和の可能性があるか、さまざまな見積もり がなされている。例えば、Paustian et al. (1997) では、 20〜30PgC、Lal (2004) では、先史時代から現在までに 失われた全土壤有機炭素量（55～78P gC）の $50 ６ 6 \%$ 程度と見積もられているが、いずれにしろ、巨大なポテン シャルを有することが認識されている。

\section{2. 土壤炭素量増減のメカニズムと農地管理}

土壌炭素量の增減は、土䁃に投入される炭素の量 (入力) と分解されて土壤から出て行く炭素の量（出力）の差によ り決まるので、条件によって增える可能性も減る可能性も ある（図1）。以下に、どのような条件で増え、どのよう な条件で減るのか、土壤炭素の增減に影響を与える主要な 因子について解説する。

入力側の因子としては、まず、当然であるが投入される 有機物の量があげられる。自然植生下では植物体の枯死量 がこれに相当するが、地上部の落葉、落枝だけではなく、 地下部の根の枯死分や、根から分泌される浸出有機物など も含まれる。農地では、地上部と地下部の成長量から収穫 物など圃場外への持ち出し分を除いたものと、堆肥などの

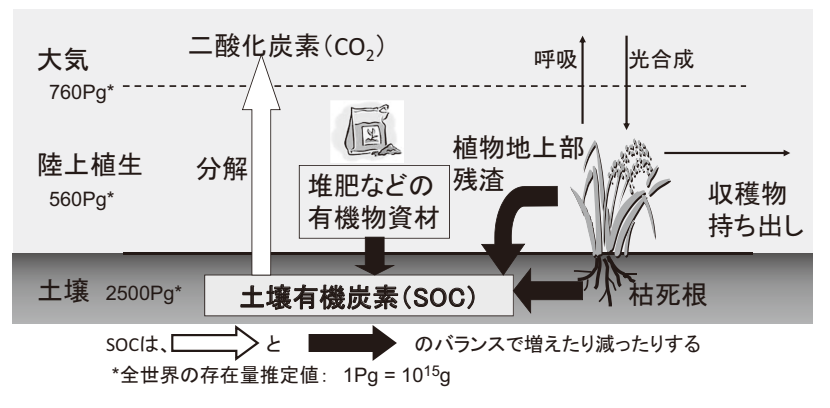

図1 土壤を中心とした炭素循環と炭素の存在量

有機資材として投入される分の合計となる。投入量の次に は、投入有機物の質、つまり分解しやすさの程度が挙げら れる。例えば、有機物の $\mathrm{C} / \mathrm{N}$ 比（炭素と窒素の比）が大 きいほど (つまり窒素に対して炭素の比率が大きいほど) 土壤中での分解は逑く、また、有機物がリグニン、セルロー スなどの難分解性の成分を多く含むほど分解が遅くなるこ となどが知られている。つまり、量だけではなく、有機物 の質も重要ということになる。

一方、出力側の因子としては、まず、温度、土壤水分な どの環境条件が挙げられる。例えば、温度が高くなれば、 土壤有機物の分解速度が大きくなる。水分では、一般に、 土壌が乾燥しすぎていても湿り過ぎていても有機物の分解 速度が遲くなることが知られている。また、土壌の基本的 な理化学性も有機物分解に影響を与える。例えば土㙵の粒 径組成では、一般に粘土質の土壤では砂質の土壤に比べて 有機炭素含量が高いが、これは、微細な粒子である粘土が 腐植と結合することにより有機物が安定化し、微生物によ

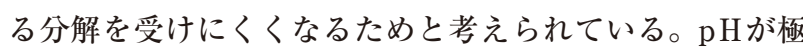
端に低い、あるいは高い土壤では微生物の活動が抑制され るため、有機物の分解が遅くなる。さらに、耕起、不耕起 などの人間による土壌管理方法の因子も挙げられる。例え ば、耕起することにより地上に落ちた作物残渣や土壤中に 存在する根、投入された堆肥などの有機物資材が土壤とよ く混合されるため、耕起は土壤有機物分解を速める効果が あると言われている。

土壤炭素量は、地球温暖化などの自然的環境条件の変化 によっても、土地利用変化や農法の変化などの人為的要因 によっても変化するが、いずれも上記の因子により説明が 可能である。例えば、水田では稲作期間中に湛水（水田に 水を張った状態）条件下に扔かれることで、有機物の分解 速度が遅くなるため、気象や土壌の母材など他の条件が同 じ場合は、畑よりも土壤炭素含量が高い。これは上記の因 子のうち、主に土壤水分因子で説明できる。また、一般に、 森林、草地などの自然植生に比べて、農地では、土壤炭素 含量が低い。これは、農地では耕起により分解が速まるこ とと、土壤に対する炭素の投入量が一般に森林や草地に比 
べて少ないことで説明できる。

土歵炭素を増加させる農地管理の例について、上述した 土壤炭素增減のメカニズムと関連付けながら以下に例示す る。土壌への炭素の投入を増加させる例としては、堆肥や 緑肥の施用が挙げられる。図2 2 、その実例で、英国のロー ザムステッド農業試験場における世界的に有名な長期連用 試験のデータである（Coleman et al., 1996）。気候や土壌 などの環境条件が同じ場所に設置された管理が異なる处理 区間の比較をすると、化学肥料に比べて堆肥を施用した場 合に土壤炭素量が多めに推移していることがわかる。これ は、単純に、炭素の投入量が多いことにより土壌炭量素が 多くなったと理解できる。類似のものとして、堆肥以外に も、緑肥やカバークロップを作付けてそれをすき达んだり、 多毛作によりすきこまれる残渣量を増やしたり、残渣の発 生量が多い品目を選んだり、といった管理が挙げられる (Ding et al., 2006)。一方、投入を増やすのではなく、分 解を遲くする管理の例としては、不耕起や省耕起栽培、す なわち、耕起による土壤のかく乱を少なくすることにより 土壌中の有機物分解を逑らせる管理法が代表的である (Smith et al., 1998; Manley et al., 2005)。ただし、最近では、 不耕起は必ずしも土壤炭素を増加させないとのデー夕も出 されている (Blanco-Canqui et al., 2008; Angers et al., 2008; West et al., 2002)。

土壤をめぐる炭素動態のメカニズムを理解することによ り、上記のようないくつかの農地管理法が土壤炭素の増加 すなわち気候変動の緩和に有効であることが定性的には理 解できる。しかし、その効果すなわち土㙥炭素の増加量を 定量的に示すのは簡単ではない。なぜなら、同じ農法を適 用した場合の効果は、前述した多数の因子に影響されるた め、場所ごとに異なるからである。

\section{3. 土壤炭素動態のモデル化と広域評価}

例えば、ある農地である量の堆肥を毎年施用した場合、 土壤炭素が何年後にどの程度増加するのか、どのようにし たら予測できるだろうか。最も確実なのは、その場所で実

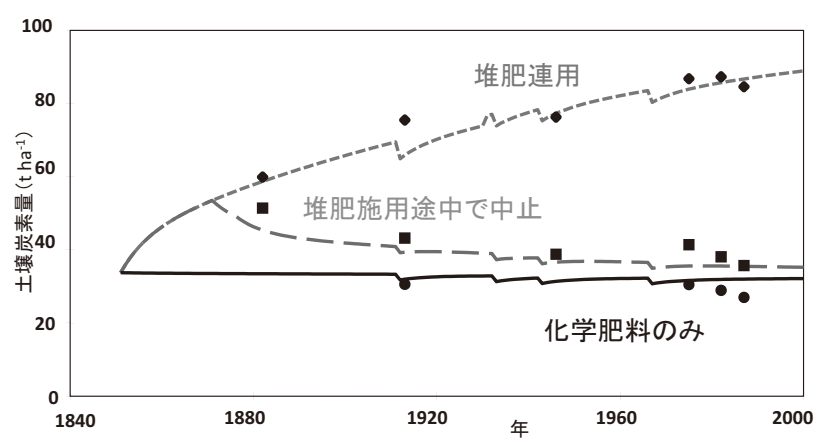

図2 英国ローザムステッド試験場における管理の違いが土壤炭 素量に及ぼす影響
際に堆肥を每年投入する実験を行うことである。たとえば 堆肥を10アールあたりそれぞれ 1 トン、3トン、 5 トン投 入する处理区を設けて土壌炭素を毎年測定する、という試 験を行えば、同じ畑で堆肥を 10 アールあたり 2 トンや 4 卜 ン投入した場合については、内捚によりかなり精度よく予 測できるだろう。しかし、隣の町にある別の農地で同じ結 果になるかどうかは、やってみないとわからない。また、 同じ場所でも、作る作物を変えたら？耕し方を変えたら？ 堆肥の種類を変えたら？など、違う条件でどうなるかは、 この試験だけからはわからないので、該当する条件で新た に試験を行う必要が出てくる。さらに、土壤炭素の変動は 一般にゆっくり起こるため、変動を実測により検出するに は長期間の観測が必要である。つまり、土壤の炭素動態に 影響する気候、土壤、農法などの組み合わせは多数になり、 想定される全ての組み合わせ条件下で長期の戋場試験を行 うのは事実上不可能ということになる。

そこで、「モデル化」という手法が有効になる。つまり、 全て実測しょうとするのではなく、今までに戋場試験の デー夕などから得られた結果から土壌中での有機物の集 積・分解過程に関わる主要な因子（たとえば温度、水分、 粘土含量、農法など）についての法則を導き出して一般化 し、数式であらわした土壤炭素動態モデルを構築し、それ を活用することによって未知の場所における土壤炭素蓄積 量の変動を予測するというものである。

世界では多数の土壤炭素動態モデルが提案されており （例えば、McGill（1996）によるレビュー)、さまざまに活 用されている。しかし、モデルのほとんどは欧米諸国で開 発されたもので、高緯度の温帯地域にその適用例が偏って おり、熱帯地域や、日本を含むアジアにおいてはモデルの 開発も、既存のモデルの検証も遅れていた。欧米とは気象 条件が異なり水田や黒ボク土など欧米とは異なる土壌が重 要な日本やアジアに扔いて精度良く適用できるモデルが求 められていたため、日本の長期連用試験のデー夕を使って モデルを検証、改良するという研究を行ってきた。その結 果、英国で開発されたローザムステッド・カーボン・モデ ル (Rothamsted Carbon Model: RothC; Coleman et al., 1996）（図3）について、日本の農耕地の半分を占める水 田土壤と、畑の半分を占める黒ボク土では、モデルの改良 が必要となり、黒ボク土以外の畑土壤では改良なしで使え ることが明らかとなった（白戸, 2006)。

このようにモデルを現実のデータで検証し、必要に応じ て改良することによって、予測結果の信頼性が大きく向上 し、人間が土壌管理を変えた場合や、温暖化が進んで気候 が変化した場合に土壤炭素の蓄積量がどう変化するか、精 度良く予測することが可能になる（図4）。

次に、こうして検証したモデルを活用して、日本全国の 


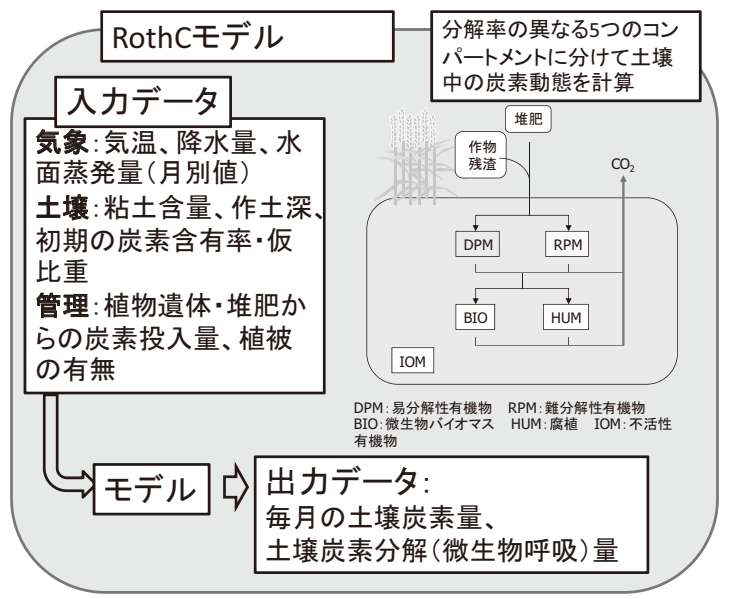

図3 ローザムステッド・カーボン・モデル (RothC) の概要

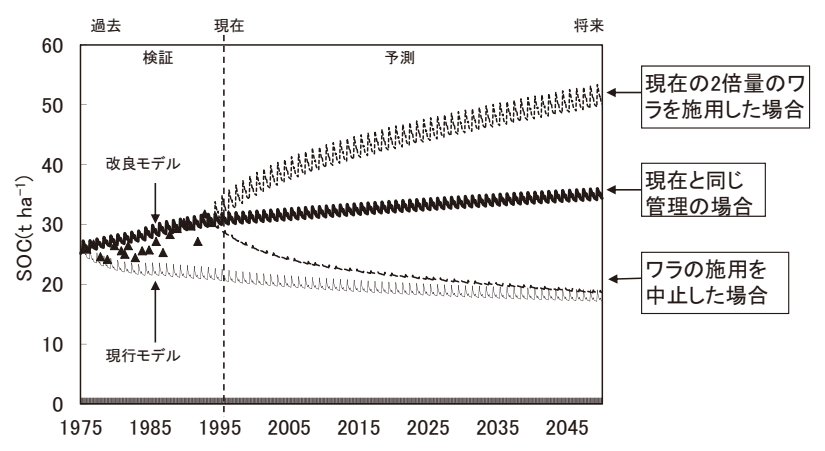

図4 水田におけるRothCの検証・改良および将来予測の例

土袞炭素の蓄積ポテンシャルを試算した結果を紹介する。 Yokozawa et al. (2010) は、RothCを日本の全農耕地に $1 \mathrm{~km}$ 解像度で適用することにより、有機物の投入量増加 による農地土壤の炭素蓄積効果を推定した。各 $1 \mathrm{~km}$ メッ シュにおける1990年の土㙵炭素量を初期值とし、A（最低 限の有機物投入シナリオ)、B(堆肥シナリオ：堆肥として 全ての水田に $1.0 \mathrm{tC} \mathrm{ha}^{-1}$ 年 ${ }^{-1}$ 、水田以外の農地に $1.5 \mathrm{tC}$ $\mathrm{ha}^{-1}$ 年 ${ }^{-1}$ を投入)、C (水田二毛作シナリオ：現在の水田が すべて水稲単作と仮定したうえで、全ての水田で裏作に麦 を作付し、麦の残渣として $0.7 \mathrm{tC} \mathrm{ha}^{-1}$ 年-1を投入)、 $\mathrm{D}$ ( $\mathrm{B}$ とCの両方を実施）の4つのシナリオについて、土壌炭素 量の変化を 25 年間計算した。これら4つのシナリオにおけ る土滾への炭素投入量は、1990年の土壌炭素量を維持す るのに必要な炭素投入量よりも小さいため、25年後には 土壌炭素は 4 のシナリオ全てにおいて減少したが、各シ ナリオの炭素投入量の違いにより減少の程度は異なり、シ ナリオ $\mathrm{A}$ の減少が最も大きかった。そこで、 $\mathrm{B} \sim \mathrm{D}$ シナ リオと $\mathrm{A}$ との差を、B〜Dシナリオに扔ける土㙵炭素蓄 積効果とすると、その規模は 25 年間でそれぞれ $32 、 11 、$ 43MtCであった（図5)。これを単位面積当たり、1年あた りの土壤炭素蓄積量でみると、25年間の平均で、 $\mathrm{B} \sim \mathrm{D}$

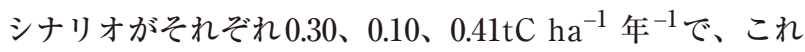

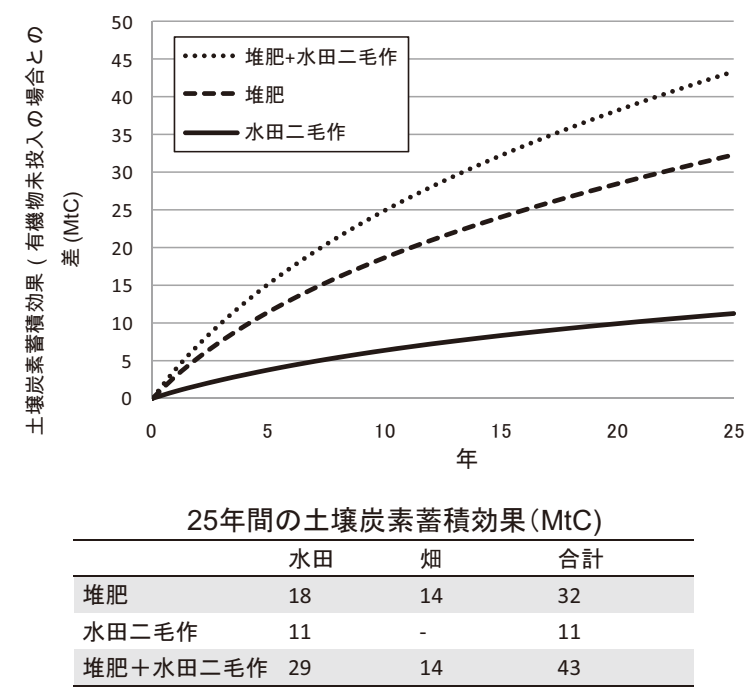

図5 全国の農地における農地管理による土壤炭素蓄積効果の試算

らの值は既往の研究例（Smith et al., 2007）と類似の值で あった。RothCモデルと土㙥の空間的分布デー夕を結びっ けるたこのシステムは、日本の農耕地土壤における有機物 投入量の増加による土壤炭素の蓄積効果を見積もるのに有 効であるが、より現実的な推定を行うためには、より現実 的で実行可能なシナリオの策定が必要であると考えられ、 現在、研究が進行中である。

\section{4. 総合評価の重要性と LCA}

土㙵炭素が増減するメカニズムを理解し、ある管理技術 の効果を定量的に予測できたとしても、その技術を導入す る前に、以下のような注意すべき点がある。1つめは、他 の温室効果ガスとのトレードオフである。有機物の投入量 を増やした時に、土壌炭素が増加したとしても、有機物の 投入は一酸化二窒素 $\left(\mathrm{N}_{2} \mathrm{O}\right)$ の発生も増加させる可能性が あり、水田に扔いては、さらにメタン $\left(\mathrm{CH}_{4}\right)$ の増加も考 虑しなければならない。これら 3 つの温室効果ガス、すな わち $\mathrm{CO}_{2} 、 \mathrm{CH}_{4} 、 \mathrm{~N}_{2} \mathrm{O}$ は、それぞれのガスの地球温暖化係 数 (Global Warming Potential: GWP) を考虑して、純 netGWPに換算して比較できるので、そのような評価が必 要となる。例えば、北海道の畑作地带 (Mu et al., 2006)、 北海道の泥炭地 (永田, 2006)、インドネシアの泥炭地 (Hadi et al., 2005）などで、そのような総合評価が行われている。 また、Nishimura et al. (2005) は、3つのガスを同時に連 続測定するモニタリングシステムを開発した。このような システムを用いた観測データの蓄積が、3つのガスの総合 評価のために重要となる。

2つめは、まさにこの学会が取り組んでいるLCA (Life Cycle Assessment）の導入である。例えば、「堆肥の施用」 を例にとると、土壤の炭素が増加するとしても、堆肥の製 造や運搬、散布などに土壤への炭素蓄積効果以上の $\mathrm{CO}_{2}$ 排 
出があっては意味がない。そこで、LCAにより、「全体と してどうなのか」を評価することが有効になる。農業分野 でもこの手法への期待が高まっているが、評価の例は、ま だ少数である。例えば、北海道の十勝の畑作の事例（古賀 ら，2006）では、耕起や施肥などの農法を変えた場合の土 壤炭素の増減と農作業による機械からの $\mathrm{CO}_{2}$ 排出などを総 合的に評価し、トラクタ作業や収穫物の乾燥など戋場外の 化石燃料の燃燒に由来する $\mathrm{CO}_{2}$ 排出量は土壤炭素の分解に よって発生する $\mathrm{CO}_{2}$ に比べてはるかに小さいとの結果が出 ている。一方、秋田県の八郎潟干拓地における水稲作の事 例（Harada et al., 2007）では、不耕起栽培において慣行 と比べて化石燃料の消費による $\mathrm{CO}_{2}$ 排出と $\mathrm{CH}_{4}$ 排出が減少 し、土壌炭素の違いは無く、総合的には不耕起栽培によっ て温室効果ガスの排出を減らすことができると報告されて いる。今後は、このような解析の事例を増やすことにより、 「全体としてどうなのか」を知った上で営農管理方法を選 択することができるようになることが望まれる。

3つめは、他の環境負荷とのトレードオフである。例えば、 有機物の投入増加は、硝酸性窒素による地下水污染や閉鎖 性水域での富栄養化などを引き起こす場合もある。また、 都市ゴミコンポストなどには重金属など有害物質が付加さ れるなどの問題もある。同じ温室効果ガス同士であれば、 上述したように純 netGWPを用いることでひとつの物差し で総合評価が可能となるが、異なる種類の環境負荷を比較 し、総合的に評価するには、評価手法の開発自体も大きな 研究課題となる。この面での研究の発展が今後期待される。

4 つめは、農業生産とのバランスである。例えば、新鮮な、 あるいは未熟な有機物の大量施用は、作物が窒素飢餓を起 こしたり、土壌の還元化により有害になる場合や、病害の 発生の危険もある。そもそも、土壤炭素は、農業、あるい は作物生産にとってどのような意味があるだろうか。炭素 は植物の必須元素 16 種類に含まれているが、植物は大気 中の二酸化炭素を光合成により固定するのであり、土壌中 の炭素を吸収するわけではない。つまり、土壌有機炭素は、 植物にとっては直接吸収する対象ではない。土壌中の有機 炭素は、植物遺体などの粗大有機物が微生物に分解され、 土壤に固有の腐植物質に変化するまでのさまざまな段階の 有機物として存在している。これらの有機物は、さまざま な機能を発揮して植物生産、つまり農業に役立っている。 この機能は、大きく3つに分けて考えることができる。

1）物理的性質の向上：土壤有機物は土壤の団粒形成を促 進するため、保水性、透水性、通気性が高まり、根の成長 に良い環境を形成し、耕うんを容易にし、水食や風食など の土壤侵食も軽減する。

2）化学的性質の向上：土壤有機物は、微生物による分解 の過程で、必須元素、特に窒素、リン、カリ、硫黄などを
供給する。供給は徐々に行われるため過剩の施用による害 や溶脱による損失が少なく、微量要素も含めてバランスよ く供給されるため、特定元素の欠乏も起こりにくい。また、 腐植物質はマイナスやプラスの荷電をもった吸着部位を多 量に持つため、土䁃中の陽イオンや陰イオンを保持し、作 物に有用な元素を徐々に作物に供給する一方、植物に有害 な元素を吸着し、植物への吸収を抑制して保護する。さら に、 $\mathrm{pH}$ に対して緩衝作用があるため、 $\mathrm{pH}$ の急激な変化を 抑制して植物を保護する。また、たとえば、火山灰土壤な どリン酸吸収の大きい土壌においてリン酸の不可給化を抑 制しリン酸の効果を高めるなど、粘土鉱物に吸着されやす い物質の直接的接触を避けて、植物の吸収を円滑にする効 果もある。

3）生物的性質の向上：土㙵有機物は土壤中の豊富で多様 な微生物群の栄養源として貢献し、これら微生物群は、植 物養分の供給だけでなく、病原菌との拮抗作用により病害 の抑制ももたらす。

このように、土㙵有機物は多様な機能を発揮するため、 一般的に土壤有機物の含量を高く保つことは、さまざまな 意味で土壌の肥沃度向上に役立つ。そのため、古来、農業 には有機物含量の維持増進のため堆きゅう肥の施用が不可 欠なものであった。本稿で述べてきたように、近年の地球 温暖化問題で土壤有機炭素自体が二酸化炭素の吸収源とも 排出源ともなりうることが知られてきたため、どうすれば より多くの炭素を土壤中に蓄積させることができるか、と いう視点の研究がなされているが、それはあくまで最近の 話で、長い農業の歴史における土壌有機物の意義に比べれ ば、温暖化緩和に役立つという新たな土壌炭素の意義は、 おまけのようなものと言える。

農地の土壌有機物含量の維持増進には温暖化防止や土壌 の肥沃度増進の意味があるが、多量に投入すると問題を引 き起こす場合があることも理解し、土壤を単に有機物蓄積 の場と考えるのではなく、持続的に農業生産を行うための 適切な施用を行うことが必要である。地球温暖化問題との 関連で土壌炭素の蓄積が注目を浴びている今、改めて、農 業生産を支えている貴重な資源である土壤についての認識 が広まることを期待している。

(平成 22 年 11 月 12 日受付)

\section{参照文献}

Angers D. A., Ericksen-Hamel N. S. (2008): Fullinversion tillage and organic carbon distribution in soil profiles: A meta-analysis. Soil Science Society of America Journal, 72, 1370-0374

Blanco-Canqui H., Lal R. (2008): No-tillage and soilprofile carbon sequestration: An on-farm assessment. 
Soil Science Society of America Journal, 72, 693-701

Coleman K., Jenkinson D. S. (1996): RothC-26.3-A model for the turnover of carbon in soil. In: Evaluation of Soil Organic matter Models, Springer-Verlag, Berlin, 237-246

Ding G., Liu X., Herbert S., Novak J., Amarasiriwardena D., Xing B. (2006): Effect of cover crop management on soil organic matter, Geoderma, 130, 229-239

Hadi A., Inubushi K., Furukawa Y., Purnomo E., Rasmadi M., Tsuruta H. (2005): Greenhouse gas emissions from tropical peatlands of Kalimantan, Indonesia, Nutrient Cycling in Agroecosystems, 71, 73-80

袴田共之, 波多野隆介, 木村眞人, 高橋正通, 坂本一憲 (2000)：地球温暖化ガスの土壤生態系との関わり 1. 二酸化炭素と陸域生態系, 日本土䁃肥料学雑誌, 71 , 263-274

Harada H., Kobayashi H., Shindo H. (2007): Reduction in greenhouse gas emissions by no-tilling rice cultivation in Hachirogata polder, northern Japan: Life-cycle inventory analysis, Soil Science and Plant Nutrition, 53, 668-677

IPCC, 2007: Summary for Policymakers. In: Climate Change 2007: The Physical Science Basis. Contribution of Working Group I to the Fourth Assessment Report of the Intergovernmental Panel on Climate Change [Solomon, S., D. Qin, M. Manning, Z. Chen, M. Marquis, K.B. Averyt, M. Tignor and H.L. Miller (eds.)]. Cambridge University Press, Cambridge, United Kingdom and New York, NY, USA, 18pp.

伊藤昭彦 (2002)：陸上生態系機能としての土壤有機炭素 貯留とグローバル炭素循環日本生態学会誌, 52, 189227

古賀伸久, 鶴田治雄（2006）：北海道の畑作農業から発生す る温室効果ガスのライフサイクルインベントリ分析, 農業および園芸, 81, 1101-1109

Lal R. (2004): Soil carbon sequestration impacts on global climate change and food security, Science, 304, 1623-1627

Manley J., Van Kooten G. C., Moeltner K., Johnson D. W. (2005): Creating carbon offsets in agriculture through no-till cultivation: A meta-analysis of costs and carbon benefits, Climatic Change, 68, 41-65

McGill, W. B. (1996): Review and classification of ten soil organic matter (SOM) models. In: Evaluation of Soil Organic Matter Models, Springer-Verlag Berlin,
$111-132$.

Mu Z., Kimura S. D., Hatano R. (2006): Estimation of global warming potential from upland cropping systems in central Hokkaido, Japan, Soil Science and Plant Nutrition, 52, 371-377

永田修 (2006) : 泥炭地・湿原における温室効果ガス, 土壤 の物理性, 104, 85-95

Nishimura S., Sudo S., Akiyama H., Yonemura S., Yagi K., Tsuruta H. (2005): Development of a system for simultaneous and continuous measurement of carbon dioxide, methane and nitrous oxide fluxes from croplands based on the automated closed chamber method, Soil Science and Plant Nutrition, $51,557-564$

Paustian K., Andren O., Janzen H. H., Lal R., Smith P., Tian G., Tiessen H., Van Noordwijk M., Woomer P. L. (1997): Agricultural soils as a sink to mitigate $\mathrm{CO}_{2}$ emissions, Soil Use and Management, 13, 230244

白戸康人（2006）：日本およびタイの農耕地における土壤 有機物動態モデルの検証と改良, 農業環境技術研究所 報告, $24,23-94$

Smith P., Martino Z., Cai Z., Gway D., Janzen H., Kumar P., McCarl B., Ogle S., O'Mara F., Rice C., Scholes B., Sirotenko O. (2007): Agriculture. In: Climate Change 2007: Mitigation. Contribution of Working Group III to the Fourth Assessment Report of the Intergovernmental Panel on Climate Change, Cambridge University Press Cambridge, United kingdom and New York, NY, USA, 497-540

Smith P., Powlson D. S., Glending M. J., Smith J. (1998): Preliminary estimates of the potential for carbon mitigation in European soils through no-till farming, Global Change Biology, 4, 679-685

田村憲司（1996）：地球規模の炭素循環 陸上生態系におけ る土㙵有機炭素の動態, 環境科学会誌, 9, 547-554

West T. O., Post W. M. (2002): Soil organic carbon sequestration rates by tillage and crop rotation: A global data analysis. Soil Science Society of America Journal, 66, 1930-1946

Yokozawa M., Shirato Y., Sakamoto T., Yonemura S., Nakai M., Ohkura T (2010): Use of the RothC model to estimate the carbon sequestration potential of organic matter application in Japanese arable soils, Soil Science and Plant Nutrition, 56, 168-176 